\title{
Isolation and identification of a cellulolytic Enterobacter from rumen of Aceh cattle
}

\author{
Wenny Novita Sari ${ }^{1}$, Safika ${ }^{2}$, Darmawi ${ }^{3}$ and Yudha Fahrimal ${ }^{4}$
}

1. Postgraduate student of Mathematics and Applied Sciences, Syiah Kuala University, Darussalam, Banda Aceh 23111, Indonesia; 2. Department of Veterinary Infectious Diseases and Veterinary Public Health, Faculty of Veterinary Medicine, Bogor Agricultural University, Jalan Agatis IPB, Darmaga, Bogor, Indonesia; 3. Microbiology Laboratory, Faculty of Veterinary Medicine, Syiah Kuala University, Darussalam, Banda Aceh 23111, Indonesia; 4. Parasitology Laboratory, Faculty of Veterinary, Syiah Kuala University, Darussalam, Banda Aceh 23111, Indonesia.

Corresponding author: Safika, e-mail: fikakhan@yahoo.com

Co-authors: WNS: wenny_zm@yahoo.com, Darmawi: darmawi@unsyiah.ac.id, YF: yudhafahrimal@yahoo.com Received: 25-08-2017, Accepted: 24-11-2017, Published online: 26-12-2017

doi: 10.14202/vetworld.2017.1515-1520 How to cite this article: Sari WN, Safika, Darmawi, Fahrimal Y (2017) Isolation and identification of a cellulolytic Enterobacter from rumen of Aceh cattle, Veterinary World, 10(12): 1515-1520.

\begin{abstract}
Aim: The aim of this study was to isolate and identify a cellulolytic bacterium from the rumen fluid of Aceh's cattle. Biodegradation by cellulolytic rumen bacteria can be used as a source of cellulolytic bacteria that act to degrade feed fibrous material so as to improve the quality of nutrients and digestibility of feed ingredients at a cheaper price than the use of commercial cellulase enzymes.

Materials and Methods: Samples were collected from rumen fluid of Aceh's cattle in Abattoirs (RPH) of Banda Aceh city, Indonesia, isolation, and screening of cellulolytic bacteria were done in Microbiology Laboratory, Faculty of Veterinary Medicine, Syiah Kuala University, Banda Aceh, Indonesia.

Results: The S1 isolates showed $\pm 2.5 \mathrm{~cm}$ of clear zone diameter. Microscopically, this strain was found to be a Gramnegative, Bacillus. Homology and phylogenetic tree analysis of 16S rRNA showed that S1 isolate has $91 \%$ of sequence similarity with that of Enterobacter cloacae. $91 \%$ sequence homology shown in this study proved that the S1 isolate is probably either a new species or another genus of Enterobacteriaceae.
\end{abstract}

Conclusion: Current study suggests that cellulose hydrolytic bacteria isolated from rumen fluid of Aceh cattle on Bushnell Haas medium-carboxymethylcellulose agar, and some potent cellulose degrading bacteria have been identified.

Keywords: Aceh cattle, cellulose, cellulolytic bacteria, Enterobacteriaceae, rumen.

\section{Introduction}

Indonesia is one of the tropical countries, where ruminants are fed on lignocelluloses agricultural-products (such as cereal straw, grass, and tree foliage). Aceh cattle, one of the local ruminants germplasm in Indonesia, derived from a cross between the local cattle (Bos sondaicus) and Bos indicus. Aceh cattle are scattered in the province of Aceh and cultivated for generations as meat producers. The advantages of this Aceh cattle in addition to having a high adaptability to the bad environment are adaptation to feed which generally contains high crude fiber $[1,2]$.

Ruminant stomach contains crude fiber such as cellulose, starch, and xylan as the basal feed for ruminants. Wahyudi et al. [3] have reported that the feed crude fibers were not completely converted to animal product in intensive animal farming. These materials are fermented in the rumen by microbial community including bacteria, fungi, and protozoa [4]. Rumen

Copyright: Sari, et al. Open Access. This article is distributed under the terms of the Creative Commons Attribution 4.0 International License (http://creativecommons.org/licenses/by/4.0/), which permits unrestricted use, distribution, and reproduction in any medium, provided you give appropriate credit to the original author(s) and the source, provide a link to the Creative Commons license, and indicate if changes were made. The Creative Commons Public Domain Dedication waiver (http://creativecommons.org/ publicdomain/zero/1.0/) applies to the data made available in this article, unless otherwise stated. microbial ecosystem comprised $10^{10}-10^{11}$ bacterial cells $/ \mathrm{mL}, 10^{4}-10^{6}$ protozoan cells $/ \mathrm{mL}$, and anaerobic fungi $10^{3}-10^{5}$ zoospores/mL [5]. Furthermore, the complex has an essential role in rumen to degrade feed and supplies nutrients to host, predominantly in the form of volatile fatty acids and microbial protein $[6,7]$.

Cellulose is one of the most important polysaccharides and the major component of plant cell walls. Bacteria also synthesize cellulose; moreover, it has greater tensile strength, versatility, and moldability. Due to its particular properties, the use of bacterial cellulose is required for different applications [8]. Cellulose is very difficult to degrade as it has homopolymer consisting of glucose units joined by $\beta$ 1-4 bond. The size of cellulose molecules (degree of polymerization) varies from 7000 to 14,000 glucose moieties per molecule in walls of plants. Cellulose has a crystalline structure, and it is surrounded by a tough lignin layer $[9,10]$. Rumen microbes that have been identified in the production of cellulases include bacteria, some fungi, and actinomycetes [11]. Several cellulase producing bacteria such as Bacillus, Paenibacillus, Pseudomonas, Clostridium, Cellulomonas, Thermomonospora, Ruminococcus, Bacteroides, Erwinia, Acetivibrio, Methanobrevibacter, Gluconacetobacter, and Rhodobacter species have also been identified [12-18]. 
Research on isolation and identification of novel cellulases producing enzymes from bacteria are still wide. In this study, a cellulolytic bacterium was isolated from rumen fluid of Aceh cattle. Biodegradation product in rumen can be used as a source of cellulolytic bacteria that act to degrade fibrous feed material so as to improve the quality of nutrients and digestibility of feed ingredients at a cheaper price than the use of commercial cellulase enzymes.

\section{Materials and Methods \\ Ethical approval}

This research was approved by the Animal Ethics Committee of Faculty of Veterinary Medicine, Syiah Kuala University (Approval No. 014/KEPH-C/ III/2017). The samples used are rumen fluid waste from abattoirs (RPH) in Banda Aceh. Handling of cattle at abattoirs in accordance with good animal practices required by the Animal Ethics Committee and regulatory guidelines and local regulations.

\section{Sample collection}

Five of Aceh cattle in which each cattle were taken $5 \mathrm{~mL}$ of rumen fluid were collected from Abattoirs (RPH) in Banda Aceh using a syringe. Presterilized syringe and plastic bags were used for sample collection. The samples were taken in three replications from a cattle rumen in one take-up, covering the left, right, and middle rumen parts. This aims to make the sample homogeneous.

\section{Isolation of cellulolytic bacteria}

A sample of rumen fluid of Aceh cattle $(1 \mathrm{~mL})$ was suspended with $9 \mathrm{~mL}$ sterile double distilled water $\left({ }_{d d} \mathrm{H}_{2} \mathrm{O}\right)$ (v/v) [19]. Serial dilutions from $10^{-1}$ to $10^{-6}$ were prepared using sterilized ${ }_{d d} \mathrm{H}_{2} \mathrm{O}$. An aliquot of $1 \mathrm{~mL}$ of each dilution was inoculated into Bushnell Haas medium (BHM) agar with carboxymethylcellulose (CMC) (pH 7.0) [13,20] containing (g/L) CMC (10.0), $\mathrm{K}_{2} \mathrm{HPO}_{4}(1.0), \mathrm{KH}_{2} \mathrm{PO}_{4}(1.0)$, $\mathrm{MgSO}_{4} .7 \mathrm{H}_{2} \mathrm{O}(0.2), \mathrm{NH}_{4} \mathrm{NO}_{3}(1.0), \mathrm{FeCl}_{3} .6 \mathrm{H}_{2} \mathrm{O}(0.05 \mathrm{~g})$, $\mathrm{CaCl}_{2}(0.02 \mathrm{~g})$, and agar (20.0) [12,21] in duplicate. Plates were incubated at $39^{\circ} \mathrm{C}$ for $96 \mathrm{~h}$.

\section{Screening of cellulolytic bacteria}

Colonies of bacteria that grown in BHM media were exposed to Congo red $0.3 \%$ for 20 minutes, then the plates were washed with $1 \mathrm{M} \mathrm{NaCl}$ solution. In isolates indicating cellulose enzyme activity showing clear zone around the colony [13]. Colonies showing discoloration of Congo-Red were considered as positive cellulose-degrading bacteria. Furthermore, one pure colony with maximum clearing zone was isolated for further screening. The isolate was morphologically identified by Gram staining. The bacterium colony was cultured into a liquid medium and incubated for $96 \mathrm{~h}$. The incubation result was centrifuged at $7000 \mathrm{~g}$, the supernatant was removed, and the cell pellet was extracted for its DNA.

\section{DNA extraction}

Total DNA was extracted separately using a commercially available kit gDNA Presto ${ }^{\mathrm{TM}}$ Bacteria Mini kit (Geneaid) according to the manufacturer's instructions with slight modifications. Cell pellets were added $200 \mu \mathrm{L}$ of extraction buffer then resuspended with pipette or vortex and then $20 \mu \mathrm{L}$ proteinase $\mathrm{K}$ was added and incubated at $37^{\circ} \mathrm{C}$ for $30 \mathrm{~min}$. During the incubation of the sample, a slow inversion was applied to the tube every $10 \mathrm{~min}$. Thereafter, $200 \mathrm{~g}$ of buffer GB was added to the sample for the dissolution and vortex process for 10 seconds and then incubated at $70^{\circ} \mathrm{C}$ for $10 \mathrm{~min}$. Elution buffer was heated at $70^{\circ} \mathrm{C}$ before its use in the next stage, and added $200 \mu \mathrm{L}$ of absolute ethanol and lysis by a shaker. The next sample was inserted into tube column with $2 \mathrm{~mL}$ tube and then centrifuged 14000-16000× $\mathrm{g}$ for $2 \mathrm{~min}$. The supernatant was removed and the precipitate was transferred to a new $2 \mathrm{~mL}$ tube.

$400 \mu \mathrm{L} \mathrm{W} 1$ buffer was added to the column and centrifuged $14000-16000 \times g$ for $30 \mathrm{~s}$ then discarded the supernatant. $600 \mu \mathrm{L}$ buffer wash (which has been added ethanol) is put into the column, centrifuged $14000-16000 \times g$ for $30 \mathrm{~s}$, then discarded the supernatant, then centrifuged again $14000-16000 \times g$ for $3 \mathrm{~min}$ until the column really no supernatant, then moved to a new $1.5 \mathrm{~mL}$ tube. $30-50 \mu \mathrm{L}$ elution buffer that has been heated was added right in the middle of the column carefully. It was incubated at room temperature for 3-5 min and then centrifuged 14000-16000× $g$ for $1 \mathrm{~min}$. Tubes containing pure DNA were stored at $-20^{\circ} \mathrm{C}$ to prevent degradation until used for polymerase chain reaction (PCR).

\section{Amplification of 16S rRNA Gene}

The amplification process is done using PCR method. One of the primers (BacF) used complement to sustainable regions in the bacterial and other primary domains (UniB) is based on universal sustainability of the 16S rRNA gene Escherichia coli [22]. The total DNA was used as a template in PCR to amplify $16 \mathrm{~S}$ rRNA. The primers used for detecting the rumen bacteria of Aceh cattle were not a universal primer, but specific primers for bacteria [23,24]. Primer is a component of PCR that determines the accuracy of DNA sequences that want to be amplified. The sequence of primary nucleotides will be the determinant on which part of the primer will attach (anneal) to the genome. If the nucleotide sequence does not match the gene code we want, we can be sure that the resulting PCR product will be mistaken. Therefore, before stepping on the amplification stage with PCR, the primer to be used should be ascertained before its specificity.

Primers used in amplification generally consist of two types, namely, forward and reverse. The primary forward moves in the direction of the 5' -3 ' DNA template strand. While reverse primers move in the direction of 3' 5' DNA template strand. The forward primer sequence was 5' AGAGTTTGATC(A/C) TGGCTCAG 3' and the reverse primer sequence was 5, GGTTAC(G/C)TTGTTACCTGCCGGA 3' [23], with an expected amplicon size of $1500 \mathrm{bp}$. 
Subsequently, 16S rRNA was amplified using the Master mix (Fermentas). A total of $25 \mu \mathrm{L}$ of reaction mixture consisted of $10 \mathrm{pmol}$ of each primer, $30 \mathrm{ng}$ of template DNA, and $12.5 \mu \mathrm{L}$ of Master mix (Fermentas). The PCR amplification was carried out for 30 cycles [25]. Each cycle consisted initial denaturing at $95^{\circ} \mathrm{C}$ for $5 \mathrm{~min}, 1 \mathrm{~min} 95^{\circ} \mathrm{C}, 30 \mathrm{~s}$ of annealing at $50^{\circ} \mathrm{C}$, and $2 \mathrm{~min}$ of elongation at $72^{\circ} \mathrm{C}$, with a final extension at $72^{\circ} \mathrm{C}$ for $10 \mathrm{~min}$ [14]. PCR product was determined by electrophoresis analysis in $1.0 \%$ agarose and $1 \times$ TAE buffer $(40 \mathrm{mM}$ Tris $\mathrm{HCl}, 40 \mathrm{mM}$ acetate, $1.0 \mathrm{mM}$ EDTA) under gel Doc (Biorad).

\section{Phylogenetic analysis}

The sequencing results were compared using the basic local alignment search tool program on NCBI http://www.ncbi.nlm.nih.gov. and 16S rRNA gene sequence homology analysis using Genbank data. A phylogenetic tree was constructed using distance matrices by the neighbor-joining model of the MEGA 6.1 program, with substitution method maximum composite likelihood [26]. The node reproducibility for tree topology was estimated by bootstrap analysis 1000 replicate data sets.

\section{Results}

\section{Isolation and screening of cellulolytic bacterium}

Several colonies of cellulolytic bacteria were isolated from the rumen fluid of Aceh cattle on BHM$\mathrm{CMC}$ agar, and cellulolytic activity quantitatively screens using Congo red staining $0.1 \%$. The bacterium was isolated on $\mathrm{pH} 6.0-6.5$ and temperature $36-39^{\circ} \mathrm{C}$. Based on the calculated cellulolytic index on clear zone diameter, $\mathrm{S} 1$ isolate had cellulolytic activity + $2.5 \mathrm{~cm}$ (Figure-1). The isolate has greater cellulolytic activity than $>1.0$ as an indication of high cellulolytic activity [27]. Microscopically, this strain was found to be rod-shaped and Gram-negative (Figure-2).

\section{Analysis of 16S rRNA and Phylogenetic analyses}

Homology analysis showed that isolate S1 has 91\% sequence similarity with that of Enterobacter cloacae. The 16S rRNA sequence of S1 was kept in NCBI database with accession number MF144569. The phylogenetic tree constructed using MEGA 6.0 demonstrated that the $\mathrm{S} 1$ isolate is related to E. cloacae (Figure-3). The bacterial identification using 16S rDNA gene sequence is a widely practiced technique for microbial diversity in nature [28]. It is believed that when a sequence has a $>98 \%$ similarity to a $16 \mathrm{~S}$ rDNA of a known bacterium, it is considered to be a member of that species. However, if the percentage of homology is $<97 \%$ the isolate is considered different [29]. 91\% sequence homology shown in this study proved that the $\mathrm{S} 1$ isolate is probably either a new species or another genus of Enterobacteriaceae. A further study such as DNA-DNA hybridization, G-C content, and free fatty acid analysis is needed to confirm the S1 status.

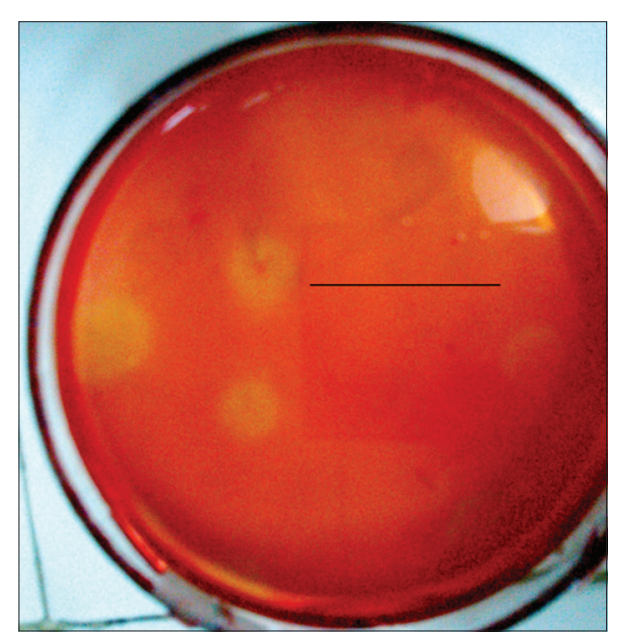

Figure-1: Zone of clearance on cellulose Congo Red agar plates for isolate $\mathrm{S} 1$ after $72 \mathrm{~h}$ of incubation. The formation of clearing zone around the colonies confirms the secretion of extracellular cellulase.

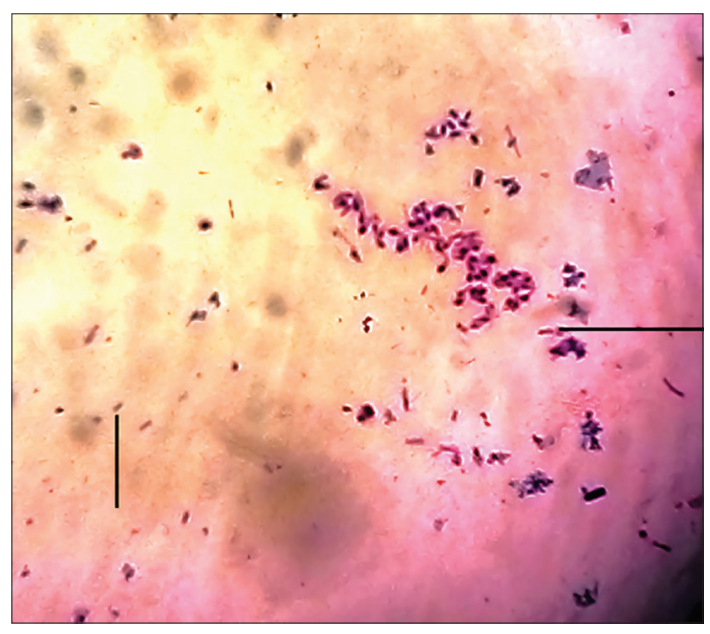

Figure-2: Gram staining of the cellulolytic bacterium.

\section{Discussion}

Cellulose in the media was hydrolyzed due to a cellulolytic enzyme produced by the bacteria. The hydrolysis process produced clear zone in BHMCMC media due to the reaction between Congo red with $\beta$-1,4-glycosidic contained in cellulose polymer. In screening for cellulase, BHM-CMC used as the substrate for endoglucanase. The activity of endoglucanase cultivated in medium indicated a relatively stable level of enzyme production during such a 3-week cultivation. A stable level of cellulolytic activity was detected also during long-term incubation [21,30].

Cellulolytic bacteria from rumen of the cattle were reported to have the optimal $\mathrm{pH}$ range of 6-6.5 and an optimal temperature of $37-39^{\circ} \mathrm{C}$. Song et al. [31] reported that the cellulases from rumen bacteria retain $70 \%$ of its activity in the $\mathrm{pH}$ range from 5 to 7 and in a temperature range from $30^{\circ} \mathrm{C}$ to $50^{\circ} \mathrm{C}$. pH of ruminants ranges from 5 to 7 , under normal dietary conditions and the ruminal temperature can vary from 


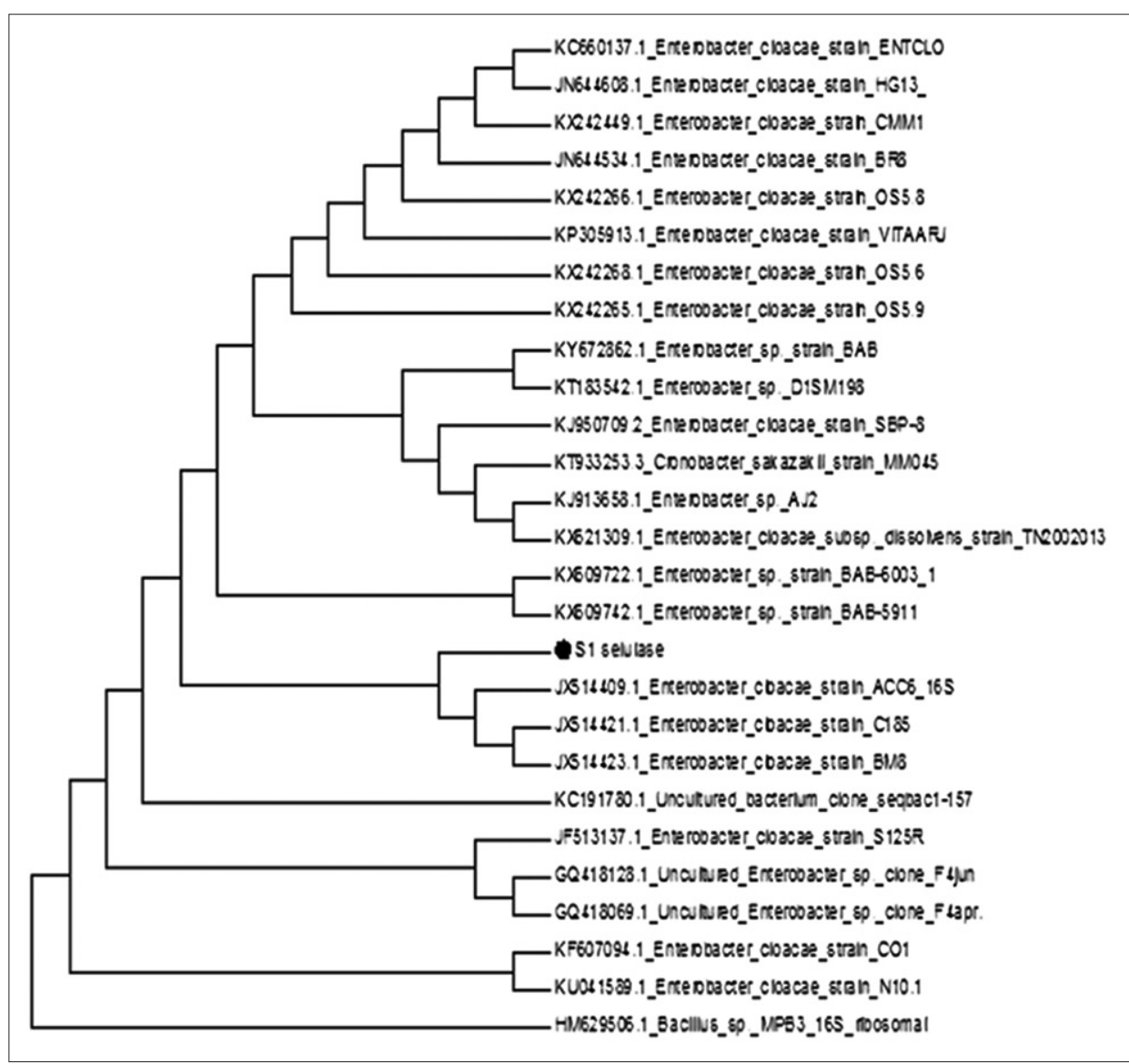

Figure-3: Phylogenetic dendrogram of the 16S rRNA sequence of the isolated strain.

$38^{\circ} \mathrm{C}$ to $41^{\circ} \mathrm{C}$. The cellulolytic reactions of bacteria rumen have been reported to be relatively more resistant to the $\mathrm{pH}$ of 6.5-7 in culture.

E. cloacae is a Gram-negative, rod-shaped, facultative anaerobic bacterium producing biohydrogen such as formate, acetate, lactate, and ethanol. E. cloacae also has the ability to degrade lignin, hemicellulose, and cellulose [32-35]. Species of the Enterobacter are widely encountered in nature as in soil, plants but they are also pathogens and not all Enterobacter bacteria produce cellulase [36]. Enterobacter in rumen of Aceh cattle found in this study may be originated from soil, grass, straw, and foliage consumed. The bacterium has the ability to degrade cellulose contain in the feed.

Naturally, cellulase is synthesized by plants, animals, bacteria, fungi, insect, and protozoa [37]. E. cloacae produce cellulose three different enzymes, a complex of endo- $\beta$ - 1,4-gluconase, a complex of exo- $\beta-1,4$-gluconase, and $\beta-1,4$-glucosidase $[36,38]$. Endoglucanase cleaves internal b-1,4-glycosidic bonds in cellulose fibers, so more free short cellulose chains. Exoglucanase hydrolyzes cellulose by release the cellobiose (b-1,4-linked glucose dimer) unit from non-reducing end of cellulose. Finally, cellobiose is hydrolyzed into two glucose monomers by b-glucosidase [39]. Hydrolysis of cellulose needs synergistic activity from various cellulases with a different specification to yield multienzyme system. The same activity is also needed to degrade cellulose molecule, product yield, and movement of cellulose chain catalytic. Cellulose multienzyme system is a microbe strategy to increase effectivity cellulase hydrolysis where each enzyme has specific function [40-42].

The microbe in the rumen can hydrolyze and ferment cellulosic polymers, so the host to get energy from the indigestible polymers. Hydrolysis of cellulose through endoglucanase and exoglucanase has been characteristic of biomass in rumen. Cellobiose, one of the major products of cellulose hydrolysis. Kajikawa and Masaki [43] reported that cellobiose intracellular hydrolysis in the rumen is considered to be more efficient than extracellular hydrolysis. Cellobiose into the cell through intracellular b-glucosidase into glucose and/or phosphorylated a derivative of glucose, which is then metabolized through central metabolism. The intracellular cellobiose requires one mole of each phosphoenolpyruvate (PEP) and ATP to produce two moles of glucose-6 phosphate. Whereas two moles of PEP are required when cellobiose is extracellularly hydrolyzed into two glucose molecules. Therefore, rumen microbial communities in ruminants are interesting sources of cellulases because these communities have adapted to utilization of lignocellulosic plant biomass.

\section{Conclusion}

Based on the result, the cellulolytic bacterium has been successfully isolated from rumen fluid of Aceh cattle that has $91 \%$ sequence similarity of $16 \mathrm{~S}$ 
rRNA with $E$. cloacae and has cellulolytic activity index $\pm 2.5 \mathrm{~cm}$.

\section{Recommendations}

Furthermore, this research should proceed to determine whether the isolate is as a new species through certain analysis DNA-DNA hybridization, $\% \mathrm{G}+\mathrm{C}$ content and free fatty acid analysis.

\section{Authors' Contributions}

Darmawi and Safika designed the study. WNS collected and processed the samples for isolation and screening of cellulolytic bacteria. WNS and Safika were done DNA extraction, PCR, and Phylogenetic analysis. YF and Safika interpreted the results and analyzed the data. All authors contributed equally in preparation and revision of the manuscript. All authors read and approved the final manuscript.

\section{Acknowledgments}

The authors are highly thankful to Directorate General of Research and Development Strengthening Republic Indonesia, for funding of the work grant from the Fundamental (No. 305/SP2H/PL/Dit.Litabmas/ II/2015)..

\section{Competing Interests}

The authors declare that they have no competing interests.

\section{References}

1. Martojo, H. (2003) Indigenous bali cattle: The best suited catlle breed for sustainable small farms in Indonesia. Laboratory of animal breeding and genetics. Faculty of Animal Science. Bogor Agricutural University, Indonesia.

2. Abdullah, M.A.N., Noor, R.R., Martojo, H., Solihin, D.D. and Handiwirawan, E. (2007) Phenotypic diversity of Aceh cattle in nanggroe Aceh darussalam. J. Indonesian. Trop. Anim. Agric., 32(1): 11-12.

3. Wahyudi, A., Cahyanto, M.N., Soejono, M. and Bachruddin, Z. (2010) Potency of lignocellulose degrading bacteria isolated from Buffalo and horse gastrointestinal tract and elephant dung for feed fiber degradation. $J$. Indonesian Trop. Anim. Agric., 35(1): 34-41.

4. Miron, J., Ghedalia, D.B. and Morisson, M. (2001) Invited review: Adhesion mechanism of rumen cellulolytic bacteria. Int. J. Dairy Sci. Process, 84(6): 1294-1309.

5. Kamra, D.N. (2005) Rumen microbial ecosystem. Special Section. Curr. Sci., 89(1): 122-243.

6. Stiverson, J., Morrison, M. and Yu, Z. (2011) Populations of select cultured and uncultured bacteria in the rumen of sheep and the effect of diets and ruminal fractions. Int. J. Microbiol. Res., 75: 165-174.

7. Hungate, R.E. (2013) The Rumen and its Microbes. Elsevier-Academic Press, New York. pp3-4.

8. Keshk, S.M.A. (2014) Bacterial cellulose production and its industrial applications. J. Bioprocess. Biotech., 4: 150.

9. Ekinci, M.S., Martin, J.C. and Flint, H.J. (2002) Expression of a cellulase gene, ce1 A, from the rumen fungus Neocallimastix patriciarum in Streptococcus bovis by means of promoter fusions. J. Biotechnol. Lett., 24: 735-741.

10. Lai, M.J., Chang, J.Y., Lee, H.Y., Kuo, C.C., Lin, M.H., Hsieh, H.P., Chang, C.Y., Wu, J.S., Wu, S.Y., Shey, K.S. and Liou, J.P. (2011) Synthesis and biological evaluation of 1-(4'-Indolyl and 6'-Quinolinyl) Indoles as a new class of potent anticancer agents. Eur. J. Med. Chem.,
46: 3623-3629.

11. Wang, Y. and McAllister, T.A. (2002) Rumen microbes, enzymes and feed digestion-a review. AJAS, 15(11): 1659-1676.

12. Ling, L.Y., Zhang, Z., Wu, M., Wu, Y. and Xun, F.J. (2014) Isolation, screening, and identification of cellulolytic bacteria from natural reserves in the subtropical region of China and optimization of cellulase production by Paenibacillus terrae ME27-1. Biomed. Res. Int., 2014: 13.

13. Singh, S., Moholkar, V.S. and Goyal, A. (2013) Isolation, identification, and characterization of a cellulolytic Bacillus amyloliquefaciens strain SS35 from rhinoceros dung. ISRN Microbiol., 2013: Article ID 728134.

14. Safika, Madayanti. F., Aditiawati, P. and Akhmaloka. (2013) Succession culture independent bacterial during manure composting process. J. Pure Appl. Microbiol., 7(13): 269-276.

15. Moon, C., Gagic, D., Ciric, M., Noel, S., Summers, E., Li, D., Atua, R., Perry, R., Sang, C., Zhang, Y. and Schofield, L. (2014) Exploring Rumen Microbe Derived Fibre-Degrading Activities for Improving Feed Digestibility. In: Proceedings of the 5 Australasian Dairy Science Symposium. p377.

16. Gupta, P., Samant, K. and Sahu, A. (2012) Isolation of cellulose-degrading bacteria and determination of their cellulolytic potential. Int. J. Microbiol. Res., 2014: 578925.

17. Mohite, B.V. and Patil, S.V. (2014) Physical, structural, mechanical and thermal characterization of bacterial cellulose by G. hansenii NCIM 2529. Carbohyd. Polym., 106: 132-141.

18. Morgan, J.L., Strumillo, J. and Zimmer, J. (2013) Crystallographic snapshot of cellulose synthesis and membrane translocation. Nature, 493: 181-186.

19. Huang, S., Sheng, P. and Zhang, H. (2012) Isolation and identification of cellulolytic bacteria from the gut of Holotrichia parallela Larvae (Coleoptera: Scarabaeidae). Int. J. Mol. Sci., 13(3): 2563-2577.

20. Ruijssenaars, H.J. and Hartmans, S. (2001) Plate screening methods for the detection of polysaccharase-producing microorganisms. Appl. Microbiol. Biotechnol., 55(2): 143-149.

21. Dziga, D. and Flasinska, D.J. (2015) Wheat straw degradation and production of alternative substrates for nitrogenase of Rhodobacter sphaeroides. Acta Biochim. Pol., 62(2): 395-400.

22. Aminin ALN, Madayanti F, Aditiawati P and Akhmaloka. (2008) Simple Enrichment and Independent Cultures to Expand Bacterial Community Analysis from Gedongsongo Hot Spring. J Biosci. Bioeng 106(2): 211-214.

23. Baker, G.C., Smith, J.J. and Cowan, D.A. (2003) Review and re-analysis of domain specific $16 \mathrm{~S}$ primers. J. Microbiol. Meth., 55: 541-555.

24. Klindworth, A., Pruesse, E., Schweer, T., Peplies, J., Quast, C., Horn, M. and Glöckner, F.O. (2013) Evaluation of general 16S ribosomal RNA gene PCR primers for classical and next-generation sequencing-based diversity studies. Nucleic Acids Res., 41(1): 1-11.

25. Shao, K., Ding, W., Wang, F., Li, H., Ma, D. and Wang, H. (2011) Emulsion PCR: A high efficient way of PCR amplification of random DNA libraries in aptamer selection. PLoS One, 6(9): e24910.

26. Tamura, K., Stecher, G., Peterson, D., Filipski, A. and Kumar, S. (2013) MEGA6: Molecular evolutionary genetics analysis version 6.0. Mol. Biol. Evol., 30(12): 2725-2729.

27. Gaur, R. and Tiwari, S. (2015) Isolation, production, purification and characterization of an organic-solvent-thermostable alkalophilic cellulase from Bacillus vallismortis RG-07. BMC Biotechnol., 15: 19.

28. Griffiths, R.I, Whiteley, A.S, O'donnell, A.G. and Bailey, M.J. (2000) Rapid method for coextraction of DNA and RNA from natural environments for analysis of ribosomal DNA and rRNA-based microbial community composition. Appl. Environ. Microbiol., 66: 5488-5491. 
29. Janda, J.M. and Abbot, S.L. (2007) 16S rRNA gene sequencing for bacterial identification in the diagnostic laboratory: Ploses, perils, and pitfalls. J. Clin. Microbiol., 5(9): 2761-2764.

30. Hatami, S., Alikhani, H.A., Besharati, H., Salehrastin, N., Afrousheh, M. and Yazdani, J.Z. (2008) Investigation on aerobic cellulolytic bacteria in some of north forest and farming soils. Am. Eur. J. Agric. Environ. Sci., 3(5): 713-716.

31. Song, Y.H., Tai, L.K., Baek, J.Y., Ju, K.M., Joo, K.Y., Rim, P.M., Ko, H., Sung, L.J., Ra, K.M. and Sung, K.K. (2017) Isolation and characterization of a novel endo- $\beta-1,4$-glucanase from a metagenomic library of the black-goat rumen. Braz. J. Microbiol., 48: 801-808.

32. Borji, M., Rahimi, S., Ghorbani, G.J.V., Yoosefi, J.V. and Fazaeli, H. (2003) Isolation and identification of some bacteria from termites gut capable in degrading straw lignin and polysaccharides. J. Vet. Res., 58(3): 249-256.

33. Ramin, M., Alimon, N. and Abdullah, K.K. (2009) Identification of cellulolytic bacteria isolated from the termite Coptotermes curvignathus (Holmgren). J. Rapid. Meth. Autom. Microbiol, 17(1): 103-116.

34. Harun, N.A.F., Baharuddin, A.S., Zainudin, M.H.M., Bahrin, E.K., Naim, M.N. and Zakaria, R. (2013) Cellulase from oil palm. Bio Resour., 8(1): 676-687.

35. Campos, E., María, J.N.A., Gonzalo, S.L., Sergio, G., Marcela, R., Paola, T., Daniel, H.G., Paloma, M.S., Mercedes, B.P., Felicia, S. and Angel A.C. (2014) Purification and characterization of a GH43-xylosidase from Enterobacter sp. identified and cloned from forest soil bacteria. Microbiol. Res., 169: 213-220.

36. Lokapirnasari, W.P., Nazar, D.S., Nurhajati, T., Supranianondo, K. and Yulianto, A.B. (2015) Production and assay of cellulolytic enzymeactivity of Enterobacter cloacae WPL 214 isolated from bovine rumen fluid waste of Surabaya Abbatoir, Indonesia. Vet. World, 8(3): 367-371.

37. Wilson, D.B. (2011) Microbial diversity of cellulose hydrolysis. Curr. Opin. Microbiol., 14(3): 259-263.

38. Mathew, G.M., Sukumaran, R.K., Singhania, R.R. and Pandey, A. (2008) Progress in research on fungal cellulases for lignocellulose degradation. J. Sci. Ind. Res., 67: 898-908.

39. Singhania, R.R., Patel, A.K., Sukumaran, R.K., Larroche, C., Pandey, A. (2013). Role and significance of beta-glucosidases in the hydrolysis of cellulose for bioethanol production. Bioresour. Technol., 127: 500-507.

40. Liu, D., Chen, X., Yue, Y., Chen, M. and Wu, Q. (2011) Structure and rheology of nanocrystalline cellulose. Carbohyd. Polym., 84: 316-322.

41. Irwin, D.C., Zhang, S. and Wilson, D.B. (2001) Cloning expression and characterization of a family 48 exocellulase, cel48a, from Thermobifida fusca. Eur. J. Biochem., 267: 4988-4997.

42. Beg, Q.K.M., Kapoor, L., Mahajan, G. and Hoondal, S. (2001) Microbial xylanase from the newly isolated Bacillus sp. strain BP-23. Can. J. Microbiol., 39: 1162-1166.

43. Kajikawa, H. and Masaki, S. (1999) Cellobiose transport by mixed ruminal bacteria from a cow. Appl. Environ. Microbiol., 65: 2565-2569. 